\title{
Occupational diseases in veterinary medicine
}

\author{
Serhat $\operatorname{Ayan}^{1}$ (D), Oytun Erbaş ${ }^{\mathbb{D}}$ \\ ${ }^{1}$ Çukurova University, Faculty of Ceyhan Veterinary Medicine, Adana, Turkey \\ ${ }^{2}$ Department of Physiology, Istanbul Bilim University, Faculty of Medicine, Istanbul, Turkey
}

\begin{abstract}
Veterinarians are individuals who carry out research and breeding activities in the field of animal husbandry, provide healthy breeding of domestic animals, protect animal food hygiene, increase production and productivity, diagnose and treat diseases in animals, and contribute to the development of the country by carrying out preventive medicine practices against epidemic diseases. Veterinarians working in animal hospitals, clinics, stables, farms, animal shelters, feed factories, pharmaceutical industry, meat processing facilities, zoos, and similar workplaces may be exposed to infection. Infection occurs as a result of animal or human contact and veterinarians are especially vulnerable to temporary or permanent zoonosis diseases, otherwise known as veterinary diseases. This review aims to provide information about zoonotic occupational diseases commonly encountered in veterinary medicine in our country.

Keywords: Occupational disease, veterinary, zoonosis.
\end{abstract}

Approximately $25 \%$ of infective diseases that threaten public health are zoonotic. Diseases which can be naturally transmitted from vertebrates to humans or from humans to animals are known as zoonoses. In our country, people who are at risk of contracting zoonoses are those with close contact with animals, or veterinarians. Transmission to humans may occur through various modes such as during veterinary procedures via urine, feces, saliva, blood, tissue, airborne or droplets, through water or soil, digestion of food, or via direct contact such as animal bites or scratches. ${ }^{[1-4]}$

Significant zoonotic diseases include bacterial diseases such as anthrax, leptospirosis, brucellosis, tuberculosis, tetanus, cat-scratch disease, salmonellosis, campylobacteriosis, and yersiniosis; viral diseases such as Q fever, Crimean Congo hemorrhagic fever, and rabies; pyrogenic diseases such as toxoplasmosis, leishmaniosis, toxocariasis, cryptosporidiosis parasite; CreutzfeldJacob Disease (CJD), transmissible spongiform encephalopathy (TSE), bovine spongiform encephalopathy (BSE); or mycologic infections such as aspergillosis. Zoonotic occupational diseases encountered in veterinary medicine are classified according to etiology. ${ }^{[5-8]}$

\section{VIROLOGIC OCCUPATIONAL DISEASES}

\section{Rabies}

Rabies is a deadly disease caused by the rabies virus which is transmitted by the bite of an animal carrying the virus leading to encephalitis in humans and animals. The zoonotic disease has been known for a long time. All warmblooded vertebrae are susceptible to rabies virus. The rabies virus is an ribonucleic acid (RNA) virus of the Lyssavirus genus in the family Rhabdoviridae. Although it is not resistant in external environments, it is reported that the virus can survive for $4-5$ hours at $56^{\circ} \mathrm{C}$, one minute at

Received: January 28, 2020 Accepted: March 05, 2020 Published online: August 25, 2020 
$70^{\circ} \mathrm{C}$, two months at $0-8^{\circ} \mathrm{C}$, five weeks at depths of 1 meter in dry soil, and up to three months in animal cadavers. The rabies virus is susceptible to external factors such as ultraviolet (UV) rays. ${ }^{[9]}$ Under normal circumstances, infection occurs only when the virus in the saliva is transmitted through open wounds from a bite or scratch from the rabid animal. Other than this, it has also been reported that the rabies virus can be transmitted as an aerosol. Iatrogenic transmission via tissue transplantation or injections have also been reported. Incubation is approximately 20-90 days. The incubation period may vary depending on the location and severity of the bite, and the amount of virus that was transmitted during the bite. ${ }^{[10]}$ Three clinical stages are observed: prodrome, furious rabies, and paralysis. After the patient is bit by the rabid animal, the virus multiplies in muscle cells or can directly enter the nervous system without replicating in the muscle tissue of entry. From here, it enters the spinal cord through peripheral nerves and rapidly spreads throughout the central nervous system. After replication in the central nervous system (CNS) it spreads to tissues and organs, again through peripheral nerves. Before the virus enters the CNS, the virus may remain in muscle tissue for days, however, once it enters the spinal cord, it rapidly passes into the CNS through dorsal root ganglia into the spinal cord via axoplasmic transport. In the brain, the virus affects the hippocampus, ganglionic cells of the pontine nuclei, and Purkinje cells of the cerebellum, resulting in lethal neural degeneration and encephalitis. In autopsies, intracytoplasmic eosinophilic Negri bodies are observed in the brain. Negri bodies are specific to the rabies disease. Observance of Negri bodies is "pathognomic" for rabies, however they may be absent in $20 \%$ of cases; therefore, presence of Negri bodies ensures pathologic diagnosis, while their absence does not necessarily mean rabies virus is absent. Progression of the rabies virus in the CNS does not induce immune response. ${ }^{[11]}$ Laboratory diagnosis of rabies virus consists of identifying rabies antigen or nucleic acid with real time-polymerase chain reaction (RT-PCR), growth of virus in cell culture or rat brain, Enzyme-Linked ImmunoSorbent Assay (ELISA), neutralization or immunofluorescent serologic tests, postmortem brain biopsy, or observation of the suspected rabid animal, comprised of euthanizing the animal in order to perform laboratory examination of nerve and brain tissue. Other animals are kept under surveillance for up to 10 days and as soon as they exhibit symptoms of rabies they are euthanized and their tissues are analyzed. If the animal is cleared of suspicion after 10 days, the patient is assessed according to clinical manifestation together with public health teams. The person who was bit by a rabid or suspected rabid animal is applied local wound treatment, administered antiserum, and vaccinated. Nowadays, human diploid cell culture plaques or fetal rhesus lung cells infected with inactivated rabies virus are used to produce the human rabies vaccine. ${ }^{[12]}$

\section{Crimean Congo hemorrhagic fever}

Crimean Congo hemorrhagic fever virus is a member of the Orthonairovirus genus of the Nairoviridae family. ${ }^{[13]}$ It is transmitted to humans via ticks of the Hyalomma genus and symptoms of the disease include fever, chills, shivers, widespread muscle aches, headache, redness in the face and eyes, nausea, vomiting, and hemorrhage that starts with complaints of diarrhea, and can lead to death. ${ }^{[14]}$ The disease begins in March and occurs until September, and especially peaks in July. It is mainly transmitted to humans by ticks, when the virus is transmitted through salivary secretions when they suck blood from the host. The tick attaches to the body and by removing it or crushing it with bare hands, the virus is transmitted with direct contact with body fluids such as saliva or blood. The disease manifests 3-14 days following the tick bite. Diagnosis of the virus is made by isolating the virus, electron microscopy, antigen and antibody detection methods, and molecular methods. ${ }^{[15]}$ Fields and picnic sites that house ticks should be avoided unless necessary. People can avoid disease by staying away from areas that contain or may contain ticks or by following methods to prevent tick attachment such as wearing protective clothing and light-colored clothing to make it easier for ticks to be noticed. ${ }^{[16]}$

\section{BACTERIOLOGIC OCCUPATIONAL DISEASES}

\section{Anthrax}

The causative agent Bacillus anthracis are gram-positive rods which are immobile, infectious, zoonotic, and animal diseases of mandatory notification; slaughter and consumption of meat 
and necropsy are prohibited. In-vitro, they appear as long chains, while in-vitro they appear as pairs or short chains similar to bamboo rods. They form spores outside of the body rather than in animal tissues and multiply in aerobic or facultative anaerobic conditions. ${ }^{[17]}$ They are easily grown in simple nutrient broths. The vegetative form dies at $60-70^{\circ} \mathrm{C}$, spore forms die at $100^{\circ} \mathrm{C}$, within 10 minutes in hot humid conditions. The bacterium lives up to 9-10 months in animal cadavers, and can survive in soil for years. Outside of living organisms, they are mostly in spore form. Endospores are resistant to disinfectant substances. They are resistant to oxidizing agents such as heat, UV, radiation, nutrient deficiency, disinfectants, $\mathrm{H}_{2} \mathrm{O}_{2}$, and have been isolated from a wide variety of living conditions, from low temperatures to high temperatures, acidic, alkaline or saline environments. ${ }^{[18]}$ They are susceptible to $5-10 \%$ formaldehyde, 2-4\% glutaraldehyde, and $\mathrm{H}_{2} \mathrm{O}_{2}$. In order to cause disease, edema factor, lethal factor, and protective antigens must be present all at once, otherwise strains that lose any of these plasmids become avirulent. Anthrax spores respirated from the air are consumed by large mononuclear cells in the alveoli, thereby passing through the alveolar wall and settling in the lymph vessels and nymph nodes. Necrosis in lymph nodes and hemorrhagic fever occur. ${ }^{[19]}$ Peracute disease in ruminants (cattle, sheep, goat, antelope), causes cerebral hemorrhage, staggering, tremor, spasm, nosebleeds, pulmonary edema, or sudden death within 1-2 hours without any symptoms. Acute disease in ruminants and Equidae leads to sudden rise in body temperature, high sensitivity to external stimuli, convulsions, edema in the neck, chest, genital organs, and lumbar region, hematuria, red-tinted milk mixed with blood, and dark non-clotting blood. Death occurs within 3-4 days; rigor mortis does not occur. In human, anthrax infection manifests in three clinical forms: cutaneous anthrax, inhalation anthrax, and gastrointestinal (GI) anthrax. In order to diagnose the disease, edema samples from the animal including blood, spleen, bone marrow, ear, or other organ tissues can be harvested. For cutaneous anthrax, swab samples of the exudate from the vesicles in the early stage can be obtained. When scar tissue forms, the scab may be lifted from its edge, and fluid can be obtained with a pipette without bleeding. For inhalation anthrax, samples can be obtained from phlegm, blood, and if necessary, cerebrospinal fluid (CSF). In GI anthrax, fecal sample can be acquired. In the event of mortality, absence of blood clotting in autopsy is an important finding in favor of anthrax. It is obligatory to dispose carcasses of animals that have died of anthrax disease by incineration or burial in pits at least two meters deep and by pouring in lime. ${ }^{[20]}$

\section{Brucella}

The intracellular bacteria Brucella spp. is a gram negative, nonsporing, nonencapsulated, nonmotile, aerobe, some of which are microaerophilic ( $B$. abortus), that causes the widespread zoonotic disease of brucellosis, also known as Malta fever. It is significant in terms of public health. Due to its long course of disease, it leads to physical incapability and loss of work force, increased treatment costs and hospital expenses, economic losses, abortus, infertility, 20\% less yield in breastmilk, and loss of breeding value. In humans, cattle, sheep, goats, horses, dogs, laboratory animals, and poultry, infection is spread through skin contact (intact and compromised skin), conjunctiva, genitalia, frozen sperm, congenitally, milking, and ticks. The bacteria can survive in moist soil for 70 days, in butter for four months, for a few days in milk, and one month in frozen temperatures. ${ }^{[21]}$ They die as a result of 30 minutes pasteurization, 45 days in brine cheese containing $10 \%$ salt, and within 1-12 hours in direct sunlight. In females who experienced abortus, uterine discharge, the fetus, fetal membrane, amniotic fluid, and placenta may carry infection. Brucella is found in the colostrum and milk of female cows, sheep, and goats that have given birth for 1-3 weeks. In bulls and rams, it may be found in sperm, urine, articular fluid, and feces. Incubation period in animals varies between two weeks to one year. Abortus is observed in 5-7-month pregnant infected animals. Abortus is $30-80 \%$ in vulnerable herds. Infertility or mastitis may occur, or if the animal is infected in the final stage of pregnancy, the offspring may die as a result of sepsis or gastroenteritis, while live offspring may be silent carriers of the disease. Epididymitis, orchitis, persistent nephritis, and infertility problems may be observed in male rams. In humans, clinical symptoms may be mistaken for a variety of diseases and they include chills, undulant fever, weakness, and joint pains. ${ }^{[22]}$ The bacteria first enter the lymph 
nodes and passes into the blood after a few days. In 2-3 weeks, infection spreads to all organs by circulation. It spreads to the uterus, which is rich in erythritol and progesterone, the breasts, testes, joints, lymphoid tissues and organs. Isolation and identification methods, serology, molecular methods, allergic methods, and animal trials may be performed in order to diagnose Brucella. For diagnosis of Brucella spp., blood, aborted fetus, cotyledones, gastral contents, liver, vaginal discharge, milk, and from dead or slaughtered animals, samples from the spleen, liver, and lymph nodes may be used. In order to treat and protection against disease, care should be taken to prevent spread of infection among the herd, hygienic precautions, elimination of source of infection, periodic disinfection, and vaccination should be conducted. Suspected infection should be examined. Animals with positive laboratory results along with other animals in the institution should be suspected for disease. Blood and milk examination should be performed every six months. Those with positive results should be slaughtered with compensation. Bulls used for breeding are examined twice in six-month intervals and those found to be positive are not used for breeding. Animals younger than one year of age are separately herded. Milk from infected animals is not mixed with milk from healthy animals, and milking is performed by separate individuals. Milk found to be positive after examination is disposed of. Birth is delivered in a separate place. Animals taken into quarantine that have not delivered an abortus or with negative results in at least two examinations are removed from quarantine. ${ }^{[23]}$

\section{Leptospira}

Leptospirosis is one of the most important zoonotic diseases worldwide, especially in developing countries located in tropical and subtropical regions. The zoonotic disease which can be acute or chronic is caused by the pathogen Leptospira serovars in humans and various animal species, particularly rodents. Water plays a significant role in the disease's epidemiology. In addition, it can survive for longer periods in neutral or mild alkaline soil and pastures. Host adaptation is also very important. An animal infected with a host-adapted serovar carries and spreads the pathogen for a long time. Pathogens without host-adaptation only incidentally cause disease and have limited time for spread. In cattle, anorexia, fever, hematuria, icterus, petechial hemorrhages, hepatitis, mastitis, nephritis, meningitis, abortion, and preterm delivery are observed. ${ }^{[1,2]}$ Host-adapted leptospirosis in cattle is caused by the L. interrogans serovar hardjo (L. hardjo). In addition, L. grippotyphosa, L. pomona, L. icterohaemorrahagiae, and other serovars may also be isolated. Pathogens colonize in both reservoirs and the renal proximal tubules of infected animals. Animals that are renal carriers play a significant role in spreading leptospirosis through urine. Other modes of transmission are the organs, milk, abortions, fetuses, infant membranes, uterine discharge, and sperm of affected animals. Direct modes include skin, mucosa, GI, vertical, and venereal transmission. Indirect modes of transmission include exposure to urine or other infected materials of carrier animals, contaminated pools, lakes, rivers, or other surface waters, sewage, drainage water from slaughterhouses, channel water, mud, soil, and similar environmental origins. Diagnosis is established using microagglutination test, dark field microscopy, ELISA, and PCR methods. For disease prevention and control, isolation of carriers, elimination of sources of infection, elimination of suspected carriers, especially rodents, preventing environmental contamination, and vaccination may be practiced. ${ }^{[17,24]}$

\section{Tuberculosis}

Tuberculosis is a significant zoonotic, chronic, infectious disease that is characterized by the formation of caseous and caseocalcareous tubercules of various organs and tissues in animals and humans, that causes great economic losses in our country and in the world and is listed among the list of diseases of compulsory notification to the World Organisation for Animal Health (OIE). The disease is caused by the Mycobacterium family of bacteria, which have unique cell wall and very slender rod-shaped bacilli structure. ${ }^{[1,2]}$ The bacteria is acid-resistant, nonmotile, non-spore-forming, kapsülsüz, can multiply in aerobic and $10 \% \mathrm{CO}_{2}$ conditions at $37^{\circ} \mathrm{C}$, has slow growth, resembles gram positive bacteria in terms of cell walls, resembles gram negative bacteria in terms of energy synthesis mechanisms, and contains hydrophobic internally and hydrophilic lipids externally in terms of wall structure. ${ }^{[17]}$ Among the Mycobacterium spp., M. tuberculosis causes tuberculosis in humans, 
M. bovis in cattle, M. avium complex in birds, $M$. microti in rodents, and M. marinum in fish. Tuberculosis is spread through nasal discharge, phlegm, cough, and fecal mode. Respiratory transmission occurs in crowded and poorly ventilated stables from the cough of infected animals. Gastrointestinal transmission occurs from meat and dairy products, and human exposure to infected animal carcasses. The pathogen encompasses a wide range of hosts such as cattle, sheep, goats, buffalo, rabbits, cats and humans, and it mostly causes infections in cattle. $M$. bovis is consumed by phagocytes once it enters the body, but it does not die and the bacilli multiply in inactive macrophages. The virulent pathogen prevents lysosome-phagosome fusion and disrupts the phagosome membrane, however, if the animal has high natural resistance and high macrophage resistance, it may also eliminate the pathogen. When the tuberculosis pathogens enter the organism and are phagocyted by macrophages, primary tuberculosis infection has started and the first stage has begun. The tuberculosis pathogens break down the macrophage and enter systemic circulation, therefore entering the symbiotic stage, or stage 2. Then, cytokines released from active macrophages and lymphocytes induce immune response, also known as stage 3. At this stage, with the effect of tumor necrosis factor-alpha, interleukin (IL)-6, IL-8, and IL-12, granuloma and tubercle formation occur in order to restrict bacilli and prevent them from multiplying and spreading. The presence of caseous necrosis regions in the center of the tubercle is an indicator of immunologic struggle. The most prominent symptoms of lung tuberculosis include dry brief cough, weight loss despite increased appetite, weakness, fatigue, difficulty breathing, increased respiratory rate, severe cough, and hemorrhagic mucopurulent nasal discharge. Gastrointestinal tuberculosis is characterized by mouth, palate, tongue, and throat lesions, difficulty chewing, difficulty swallowing, bloody stool, and abdominal pain. The most common symptom in breast tuberculosis is mastitis. In animal necropsies, swollen lymph nodes, caseous or caseo-calcareous lesions in the lungs or pulmonary lymph nodes, nodules and ulcers in nasal mucosa, nodules in the pleura, pearl disease, tubercles and ulcers in the small intestine, as well as lesions in the liver, spleen, uterus, kidney, testes, ovaries, and breast may also be observed. In the diagnosis of the disease, delayed type hypersensitivity reaction (purified protein derivative; PPD) and gamma interferon test is performed in live animals, histopathological and bacteriological tests, PCR, molecular methods, serological tests, and tuberculin test is performed in post-mortem examination. Miliary tuberculosis, generalization findings, and exudative caseous lesions indicate the presence of bacteria in the flesh. ${ }^{[17,25]}$

In local, primary complex, chronic tuberculosis which has spread to lymph nodes and several organs with microcirculation, without cachexia, the lesioned sites are disposed of, and the carcass is sent to regulatory slaughter. In generalized tuberculosis which has spread to the spleen, kidneys, testes, ovaries, breast, and bones with microcirculation, intramuscular lymph nodes, chest and abdominal cavities, cerebral membranes, and eyes, it is disposed of, if there is cachexia, lesions are also locally disposed of.

Quarantined animals with negative test results are retested with tuberculin test two months later. Those with negative test results for the second time are removed from quarantine. Feed and bedding of infected animals are burned, and their milk is disposed. Veterinary control, quality care, nutrition, restricting the entrance of uncontrolled livestock, good ventilation, allowing entrance of livestock after disinfection, feeding calves with healthy cow's milk, and tuberculin test once every six months are methods to protect against the disease. ${ }^{[26]}$

\section{Tetanus}

Tetanus is an acute, lethal intoxication caused by Clostridium tetani, which are spore-forming, gram-positive rods. It is common among humans, horses, and ruminants and is generally found in soil. Infection occurs when the spores in the soil or feces enter compromised tissue. Neonatal disease is generally very severe. It has two toxins: tetanospasmin and tetanolysin. Tetanolysin causes hemolysis and forms an anaerobic environment by reducing redox potential. Tetanospasmin is a polypeptide structure that is responsible for clinical symptoms. It is vulnerable to heat, sunlight, and chemicals. Head and neck tension are observed. Flexor and extensor muscles contract simultaneously. Food and water intake are limited due to lockjaw. Nostrils and eyes widen, and hypersensitivity to sound and light 
develops. The animal's tail is raised and the abdomen is slanted. Urination and defecation cease. Drooping of the third eyelid (only in dogs) is a pathognomic symptom of the disease. It becomes impossible for the animal to stand from laying-down position. The animal dies of paralysis (respiratory paralysis) within 2-3 days. Treatment of the sick animal includes quarantine in a semi-dark private tetanus box, free of sound and noise. It is possible to cure the disease, but slaughter is recommended in cattle infected with tetanus. Treatment may be attempted in calves. Animals that survive 13-14 days are considered to have been recovered. If the wound is present, the scab is removed and rinsed with oxygenated water. Protection from the disease is possible by vaccination. ${ }^{[27]}$

\section{Cat-scratch disease}

Bartonella henseale is a gram-negative, slightly curved, pleomorphic, generally coccobacilli, microaerophilic, intracellular bacteria. Due to its autoagglutination attribute, they form clusters in Gram staining. $B$. baciliformis and $B$. clarridgeiae are motile due to flagella, while in $B$. henselae twitching mobility is observed. Bartonellosis, or catscratch disease is a very common zoonotic disease among cats, especially in temperate regions, worldwide, found in humans and several animal species. About $30 \%$ of cats are infected. There are 20,000 cases under the age of 20 in America every year. It has been determined that clinically healthy cats who are carriers man carry $B$. henselae in their blood for at least two years and pose a risk to human health. The role of fleas (Ctenocephalides felis) is very significant. The fleas that suck the infected cat are abundant in the feces and continue to live for nine days. The nails and teeth of cats infected with fleas are contaminated with feces during scratching and licking. The disease is transmitted through fleabites, getting scratched by a cat with contaminated nails, bitten or licked by a cat with contaminated gums and saliva, and contamination of an open wound by the cat's blood or flea-ridden feces. B. henselae settles in the erythrocytes of cats.

The disease, when transmitted to humans as a result of scratching or biting of cats, does not settle in erythrocytes as in cats, but in endothelial cells of blood vessels. The disease does not produce any symptoms in cats. However, in humans it presents as a small skin lesion, usually at the entry point of the pathogen on the hand or forearm, which forms into a papule to a vesicle, then a healed ulcer. Recovery occurs within a few days. Unilateral lymphadenitis (usually axillary) occurs in progressive cases. It presents symptoms such as fever, chills, loss of appetite, and headache. In immunosuppressive patients, bacillary angiomatosis and peliosis, endocarditis, recurrent fever, bacteremia and ocular, hepatosplenic, skeletal, cutaneous and pulmonary symptoms are observed. B. henselae stimulates the growth of both itself and endothelial cells by synthesizing an angiogenic factor, "vascular endothelial growth factor" (VEGF). This protein, released by $B$. henselae, both stimulates new cell formation and prevents apoptosis of infected cells. The disease is diagnosed with culture, serological tests and PCR methods. ${ }^{[28]}$

\section{Q fever}

$\mathrm{Q}$ fever is caused by Coxiella burnetii. Coxiella burnetiid are smaller than rickettsia and differ according to $\mathrm{G}+\mathrm{C}$ ratio, vector, intracellular proliferation, antibiotic susceptibility, and resistance to extreme heat. They reproduce in phagolysosomes within the cell. They are resistant to UV rays. ${ }^{[29]}$ They have been proven to live for a long time in animal food, and dry feces of ticks. There are two structural forms: the small cell variant (SCV) that is resistant to external environmental conditions and the large cell variant (LCV) which proliferates in monocyte and macrophage cells. The disease has two forms: acute and chronic. Mortality is very low, around $1 \%$. Clinical symptoms range from asymptomatic infections to pneumonia, prolonged fever, endocarditis, and hepatitis. As with other rickets, there is no skin rash. The disease is widespread throughout the world, including Turkey. Transmission to humans may be through inhalation of contaminated particles, through digestion such as drinking raw milk, and, and skin/mucous membranes (cough droplets and laboratory accidents). ${ }^{[30]}$ Complications are rare and include systemic vasculitis and its sequelae; vasculitis results in widespread activation of the coagulation cascade, endothelial cell injury, lesions in parenchymal organs, acute renal failure, encephalitis, myocarditis, uveitis, 
bone marrow failure (with hemophagocytosis). Microbiological diagnosis is made by Rickettsia isolation, serologic, immunologic, and PCR methods. ${ }^{[31]}$

\section{PARASITOLOGIC OCCUPATIONAL DISEASE}

\section{Cystic Hydatid}

Cystic hydatid is a significant helminthic zoonotic infection caused by Echinococcus spp. and is seen worldwide in all climates. As a serious public health problem and a zoonosis, it is common in areas where animal husbandry is common. ${ }^{[32]}$ Transmission occurs when parasitic eggs which pass hand-to-mouth from infected dogs are orally ingested. Transmission to canines, definitive hosts, occurs when they consume organs of intermediate hosts containing larvae. Embryos that hatch from orally ingested eggs penetrate the intestines and settle in the target organ, adhering to the capillary and forming a cystic hydatid within five days. ${ }^{[3]}$ Growth speed varies according to the tissue it resides and may take 10-20 years. As the cyst grows, it causes mechanical damage to the surrounding tissues by compression. If the cyst wall perforates, the host may die from anaphylactic reaction. Protoscoleces spread to surrounding tissues or organs and form cysts. Intraoperative cyst perforation also later manifests as secondary recurrence of cysts. Clinical symptoms include right upper quadrant pain, cholestasis, cirrhosis, chronic coughing, phlegm, dyspnea, chest pain, and hemoptysis. It may grow for years without presenting clinical symptoms. ${ }^{[34]}$ Generalized urticaria, eosinophilia, and developmental delay in children (nonspecific) may occur. Symptoms related to the organ that contains cysts, and bile duct association in the liver may be observed. It may rupture into a large bile duct. Nauseavomiting, stomachache, feeling of fullness in the right hypochondrium, jaundice, and hepatomegaly may persist for years. ${ }^{[35]}$ Clinical symptoms become more severe as the cyst's size in the liver increases. In the lung, it grows more slowly and is more commonly seen in the right lung. Persistent cough, hemoptysis, and asthmalike attacks may be observed. Complications may occur. In the liver, compression to neighboring organs, perforation/rupture (discharging to the bile ducts, peritoneum, thorax, GI tract), bacterial infection of the cyst, rupture into the peritoneum, anaphylactic shock, and secondary cyst formation may occur. ${ }^{[36]}$ Similarly, in the lung, perforation/rupture (bronchia, pleura, pericardium, diaphragm), severe cough, salty taste in mouth due to release of cyst fluid and cyst membranes may be observed. Anaphylactic shock may occur. Definite diagnosis is made by examination of expelled cyst membranes, identifying protoscoleces or hooklets in fluid, or PCR. In order to avoid disease, infected canines must be treated, taken into surveillance, and followed up. The slaughtering of livestock should only be practiced in slaughterhouses under the control of a veterinarian; cystic organs and animal carcasses should be properly disposed of, and eradication programs should be implemented. ${ }^{[37]}$

\section{Cryptosporidiosis}

Cryptosporidium parvum is a monoxenous protozoological zoonotic disease. Transmission occurs via oral ingestion of cryptosporidium oocytes. They are found inside parasitic vacuoles in the microvilli of the intestinal epithelial cells. Schizogony, gametogony, syngamy, sporogony occur within the host. Watery and phosphorusgreen feces are important in diagnosing the disease. After conducting flotation methods, diagnosis is made using acid-fast staining (blue background, pink oocysts) and fluorescent staining. ${ }^{[32,38]}$

\section{Taeniasis}

Taennidae cause helminthic zoonotic disease. Human transmission occurs with the ingestion of raw, inadequately cooked, and unprocessed cattle meat. Cattle receive eggs in the form of prenatal infection, orally from pastures contaminated with human excretion, the use of human feces and sewage waters in agriculture, public train toilets, seagulls and similar birds. Gastrointestinal disorders, feeling of hunger, abdominal pain, diarrhea, passing of segments through the anus, colitis, appendicitis, muscle stiffness, general weakness, anorexia, and increased salivation are observed in sick animals. With proper preparation of meat products, four days at -3 degrees, four hours at -8 degrees, two hours at -15 degrees, 30 minutes at -30 degrees, or 57 degrees instantly. Consumption of properly cooked meat is important for preventing disease. 
Protecting against disease is possible by inspecting meat, preventing illegal slaughter, and treatment of infected persons. ${ }^{[32,39]}$

\section{Conclusion}

The main purpose of occupational health and safety is to protect human health and maintain safe working conditions. Zoonotic diseases operate against employees, management, and quality of production. Taking precautions against zoonotic diseases is important in order to maintain working conditions and production and increase quality. Studies have shown that it is necessary to raise awareness in groups at risk of contracting zoonoses. Today, it is reported that these studies are not sufficient. For this reason, education by authorized organizations or authorized persons to raise awareness, should be, not only during epidemics but also routinely, provided to veterinarians in the risk group and other employees in that field, to raise awareness of our young colleagues and candidates to whom we entrust our future. Preventive veterinary medicine activities for animals should be increased. Necessary measures should be established for epidemics by determining the necessary policies with the Ministry of Health and Ministry of Agriculture and Forestry. Attention should be paid to hygiene rules at every stage, from production to consumption, and necessary measures should be taken; illegal logging and uncontrolled production should be prevented. The public should be informed about the pasteurization or proper cooking of milk and dairy products. Studies should be conducted to explain the negative effects of the consumption of raw meat and meat products on public health, and the appropriate conditions for consuming products should be recommended. Pet-owners must be provided with the necessary information when obtaining pets and should follow hygiene practices and vaccination calendars. Providing training on the care and hygiene conditions of pets and zoonotic diseases through public education centers would be beneficial. In addition, insensible slaughtering of animals that have not recovered or are near death despite their treatment should be prevented. Adequate and continuous inspections should be carried out for healthy and safe farming. The public should gain awareness that animal products which are preferred for being cheap threaten public health and producer health. Illegal slaughter and distribution should be prevented and appropriate dissuasive penalties should be authorized.

\section{Declaration of conflicting interests}

The authors declared no conflicts of interest with respect to the authorship and/or publication of this article.

\section{Funding}

The authors received no financial support for the research and/or authorship of this article.

\section{REFERENCES}

1. Kurt H, Gündeş S, Geyik MF. Zoonozlar. Enfeksiyon Hastallkları. İstanbul: Nobel Tip Kitabevi; 2013. p. 419-67.

2. Firdevs A. Enfeksiyon Hastalıkları. 1. Baskı. Ankara: MN Medikal ve Nobel Basım Yayınevi; 2008.

3. Ang Ö, Tümbay E, Ang Küçüker M. Zoonozlar. 1. Baski. İstanbul: Nobel Tip Kitabevleri; 2010.

4. Kayabaşı R. Laborant ve veteriner sağlık önlisans öğrencilerin zoonotik meslek hastalıkları hakkında bilinç seviyelerinin ölçülmesi. EJOVOC 2018;8:11-20.

5. Ilıman EZ. Türkiye'de meslek hastalıkları. Uluslararası Sağlık Yönetimi ve Stratejileri Araştırma Dergisi 2015;1:21-36.

6. Gül Y, İssi M, Gül Baykalır B. Araştırma laboratuvarlarında biyogüvenlik, zoonotik hastallklar ve tıbbi atıkların bertarafı. Atatürk Üniversitesi Veteriner Bilimleri Dergisi 2013;8:81-96.

7. Budağ C. Yem fabrikalarında hijyen sorunu ve zoonoz hastalıklar. Iğdır Üniv Fen Bil Enst Der 2011;1:141-54.

8. Kasımoğlu Doğru A. Yeni-yeniden önem kazanan gida zoonozları: Etkili faktörler. Vet Hekim Der Derg 2010;81:27-30.

9. Yoldaş A, Tuzcu M, Özmen E, Yığın A, Özmen M, Kul S, Tuzcu N. Sığırlarda kuduz hastalığının teşhisi ve kuduz virüsünün anatomik lokalizasyonunun real time PCR ile belirlenmesi üzerine karşılaştırmalı çalışmalar. Dicle Üniv Vet Fak Derg 2009;2:42-50.

10. Ankara Üniversitesi Açı Ders Malzemeleri. Erişim linki: https://acikders.ankara.edu.tr/course/view. php?id=4938 [Erişim tarihi: 20.08.2019]

11. Ankara Üniversitesi Açık Ders Malzemeleri. Erişim linki: https://acikders.ankara.edu.tr/course/view. php?id=4735 [Erişim tarihi: 20.08.2019]

12. Tatan Y, Oğuzoğlu TÇ. Kuduz enfeksiyonunun moleküler evrimi, çeşitliliğ̣i ve coğrafik dağıllımı. Etlik Vet Mikrobiyol Derg 2018;29:82-6.

13. Karadakovan A. Kırım Kongo Kanamalı Ateşi (KKKA) ve Korunma. Nefr Hem Der 2010;07:19-22.

14. Bozkurt GY, Memikoğlu KO, Azap A, Balık İ. Kırım Kongo Kanamalı Ateşi: Olgu sunumu. Ankara Üniversitesi Tip Fakültesi Mecmuası 2005;58:193-6.

15. Kırdar S, Ertuğrul MB. Kırım-Kongo kanamalı ateşi. Adnan Menderes Üniversitesi Tıp Fakültesi Dergisi 2009;10:45-52. 
16. Akyazı R, Ecevit O. Keneler ve kırım kongo kanamalı ateşi. Anadolu Journal of Agricultural Sciences 2006;21:340-9.

17. Aydın N, İzgür M, Diker KS, Yardımcı H, Esendal Ö, Parmakcıoğlu J, Akan M. Veteriner Mikrobiyoloji (Bakteriyel Hastalıklar). Ankara: İlke-Emek Yayınları; 2006.

18. Kalender H, Kılıç A. Doğu anadolu bölgesindeki bazı illerde 2001-2005 yılları arasında hayvanlarda görülen anthrax olguları. YYU Vet Fak Derg 2006;17:45-7.

19. Parlak E, Parlak M. Türkiye'nin doğusunda deri şarbonu aile salgını. Sakarya Tıp Dergisi 2015;5:10-4.

20. Öğütlü A. Şarbon. J Exp Clin Med 2013;29:155-62.

21. Evirgen Ö , Köksaldı Motor V . Brusellozis. J Exp Clin Med 2013;29:149-54.

22. Günal Ö, Berk S, Barut H. Brusellozda akciğer tutulumu. J Exp Clin Med 2012;28:128-31.

23. Kuyucuoğlu Y. Brusella hastalığı. Kocatepe Veterinary Journal 2011;4:57-64.

24. Turhan V, Hatipoğlu M. Leptospiroz: "Yeni fark edilen eski bir enfeksiyon hastalığı". J Exp Clin Med 2013;29:163-8.

25. Sayın Z, Erganiş O. Sı̆̆ır tüberkülozunun teşhisinde kullanilan metotlar. Kocatepe Veterinary Journal 2010;3:77-82.

26. Kalender N, Sütçü Çiçek H. Eski değil eskimeyen hastalık: Tüberküloz. HUHEMFAD 2016;3:58-67.

27. Doğan G, Kayır S, Akdağlı Ekici A, Aşıcı E. Mortal Seyreden Tetanoz Vakasi: Olgu Sunumu. Kocaeli Medical J 2017;6:52-5.

28. Böyük A, Üstün C, Arslan Solmaz Ö, Altınsoy HB, Banlı O. Meme kanseri ile karışabilen nadir bir olgu: Kedi tırmı ̆̆ hastalığı. Fırat Tıp Dergisi 2009;14:268-70.

29. Erdenliğ Gürbilek S, Keskin O, Yiğin A, Tel OY. Ruminant abortus vakalarında Coxiella burnetii'nin real time PCR ile araştırılması. Harran Üniv Vet Fak Derg 2018;7:79-83.

30. Özbey G, Kalender H, Muz A. Q Hummasinın epidemiyolojisi ve teşhisi. JHS 2009;18:100-10.

31. Leloğlu N. Erzurum Kars ve Ağrı illerinde Q Humması üzerinde çalışmalar. Atatürk Üniversitesi Ziraat Fakültesi Dergisi 2010;8:113-31.

32. Tinar R, Umur Ş. Veteriner Parazitoloji Hayvan Türlerine Göre. Ankara: Güneş Tıp Kitabevi; 2015.

33. Yaman M. Kistik ekinokokkozis ve kontrol çalışmaları. YYU Vet Fak Derg 2011;22:121-5.

34. Ütük AE, Pekkaya S, Kuzugüden F, Balkaya İ, Şimşek S. Türkiye'nin Nevşehir İlindeki atlarda kistik ekinokokkoz seroprevalansı. Etlik Veteriner Mikrobiyoloji Dergisi 2017;28:101-4.

35. Gül A, Değer S, Cantoray R. Van ilinde kist hidatik sorunu. YYO Vet Fak Derg 1996;7:90-2.

36. Çaycı M, Tihan D. Karaciğer kist hidatik tedavisinde güncel yaklaşım. Uludağ Tıp Derg 2016;42:53-9.

37. Sağlam Y, Terim Kapakin K, Balkaya İ. Bir ceylanda (Gazelle gazelle) hidatid kist olgusu. Atatürk Üniversitesi Veteriner Bilimleri Dergisi 2011;6:239-43.

38. Usluca S, Aksoy Ü. Su Kaynaklı Bir Parazit: Cryptosporidium. DEÜ Tıp Fakültesi Dergisi 2006;20:65-74.

39. Yılmaz A, Orunç Kılınç Ö, Göz Y, Denizhan V. Van ilinde dışkı muayenesine göre sokak köpeklerinde görülen mide-bağırsak parazitleri. Muş Alparslan Üniversitesi Fen Bilimleri Dergisi 2017;5:425-9. 